\title{
Santa entre los Malditos. Culto a La Santa Muerte EN EL MÉXICO DEL SIGLO XXI
}

\author{
Felipe Gaytán Alcalá
}

Resumen: El culto a la Muerte se ha extendido en el imaginario social de distintas regiones de América Latina. Algunos le llaman San Muerte (Argentina). Muerte (Colombia), o Santa Muerte (México). Es en este último país que el culto se muestra versátil, amplio e incluyente, con características que lo hacenúnico. Loscreyentes re-inventan el tiempo social en torno a la imagen de la Santa Muerte. Conscientes de las amenazas del entorno, la violencia, inseguridad e incertidumbre que anulan su seguridad ontológica y su cotidianidad, buscan refugio en un culto que les provee una supuesta seguridad en el presente (aquíy ahora) y desplaza el futuro como un horizonte lejano. Durante mucho tiempo se creyó que sólo aquellos que viven al límite de su vida profesan tal creencia: policías, narcotraficantes, prostitutas, delincuentes. Pero el culto es transversal a distintos grupos sociales y niveles socioeconómicos quienes ahora lo muestran públicamente.

Palabra clave: Santa Muerte, riesgo, peligro, contingencia, tiempo, futuro, inclusión/exclusión.

Enviado a dictamen: 22 de febrero de 2008

Aprobación: 17 de abril de 2008.

Felipe Gaytán Alcalá, investigador, Universidad La Salle México, correo electrónico: fgaytan@ci.ulsa.mx, fgal@ulsa.mx.
Abstract: The cult of death has spread in the social imaginary from different regions of Latin America. Some people call it, San Muerte (Argentina), Muerte (Colombia), or Santa Muerte (Mexico). It is in the latter country where the cult is versatile, comprehensive and inclusive, with characteristics that make it unique. Believers re-invent the social time around the image of the Holy Death. Aware of the threat to the environment, violence, insecurity and uncertainty that nullify their safety and their everyday's ontological seeking refuge in a cult, the common citizen provides an alleged security in the present time, here and now, and transfers the future to a distant horizon. For a long time it was believed that only those people who live on the threshold of their lives may profess such a belief: police, drug dealers, prostitutes and criminals. But the cults are cutting across social groups and socioeconomic levels, and now show their support for it publicly.

Keyword: Santa Muerte, risk, danger, contingency, future, inclusion/exclusion.

$\mathrm{N}$ ada impresiona tanto a los humanos como sus propias convenciones, escribió Fernando Savater para ilustrar las angustias y temores de la sociedad frente al cambio de siglo y de milenio. Pero esa impresión no es exclusiva de momentos extraordinarios, es también extensiva a la cotidianidad, en el presente de muchos seres humanos conscientes de la angustia de morir en cualquier instante, sin saber cómo, cuándo o dónde: policías, narcotraficantes, politiquillos que 
apuestan todo, prostitutas, entre otras actividades extremas. Ellos padecen la angustia por la muerte y la han convertido en un símbolo de su actividad. Saben que no pueden pensar en un mañana sino en un presente permanente. Todo es presente, una sucesión de presentes que en cualquier momento puede interrumpirse.

En las actividades delictivas hay un desprecio por la vida, la propia y la de los otros. Los delincuentes saben que eliminar a otros puede desembocar en que mañana sean ellos las víctimas. No resulta gratuito, entonces, que cada mañana nos enteremos de ajusticiamientos, vendettas, ejecuciones y suicidios en este sub-mundo de lo excluido y marginal. Pero el desprecio por la vida no es algo sin sentido. Es la muerte la que reivindica la vida. Si la muerte careciese de sentido sería tanto decir que la propia vida no la tuvo. Cuando alguien muere de manera violenta decimos "se la buscó":

Es cierto, cada cual tiene la muerte que se busca, la muerte que se hace. Muerte de cristiano o muerte de perro son maneras de morir que reflejan maneras de vivir (...). La muerte es intransferible comola vida (...). Dime como mueres y te diré quién eres (Paz, 1990: 59).

En México, la representación de la muerte es una representación extendida y culturalmente aceptada: la tradición de los muertos el 2 de noviembre de cada año, las litografías de Posada, entre otras, se extiende por una gran parte del país. Pero es en el mundo de los "malditos" - de la delincuencia y el asesinato- donde la muerte adquiere relevancia, crueldad visible que lastima las buenas conciencias. Frente a este mundo cerrado y sin salida (parafraseando a Paz) la muerte es la única certeza. En este mundo es necesario proteger la vida rindiendo culto a la muerte para implorar su protección, para que al menos la vida no sea tan sufrida y la agonía no carcoma el sentido de vivir.

Casos extremos en el culto a la muerte han sido los llamados narcosatánicos, quienes en 1989 fueron aprendidos por el asesinato de varias personas - entre ellas el sobrino de un senador estadounidense- en rituales satánicos. Su sede de operaciones era la Ciudad de Matamoros en Tamaulipas: su actividad principal, el narcotráfico y el secuestro. Además de las armas y las influencias políticas, este grupo se dedicaba al culto satánico para asegurar el éxito de sus operaciones. En sus rituales se llevaron a cabo asesinatos de seres humanos, y el posterior uso de los huesos de sus víctimas como amuletos. El final de este grupo fue tan trágico como su vida. Algunos de ellos fueron muertos en enfrentamientos con la policía en la Ciudad de México. Otros están purgando condenas en penales de máxima seguridad.

A más de 13 años de aquel suceso, los ritos satánicos se han extendido en el tiempo y el espacio. En la Ciudad de México, Guadalajara, Matamoros, Ciudad Juárez y Culiacán, se han detectado bandas que recurren a este tipo de rituales para invocar la protección de la muerte. Aunque en algunos casos ya no recurren al sacrifico de las personas, si recurren a la tortura de sus víctimas (en el que la sangre es el símbolo central) para sus rituales.

De manera más cotidiana, el culto a La Santa Muerte se ha extendido en la Ciudad de México. Sobre todo entre los policías, delincuentes y políticos, quienes recurren al Mercado de Sonora para rituales de limpia frente a la imagen de La Santa Muerte y adquirir algunos implementos para los altares en su casa. Un lugar recurrente para la práctica de la santería y el vudú tanto de los delincuentes y policías es el Centro Esotérico Fe y Energía ubicado sobre la Avenida Insurgentes Centro.

Cabe aclarar que dicho culto no es exclusivo de grupos marginales o excluidos. También hay creyentes de diversas posiciones económicas y estratos socioculturales, incluso algunos intentos de asociaciones religiosas por apropiarse del culto e integrarlo a su doctrina como fue el caso e la Iglesia Tradicionalista México-USA (asociación que perdió su registro ante la Secretaría de Gobernación), ${ }^{1}$ la cual enfrentó múltiples conflictos por la adjudicación exclusiva que hizo del culto en sus rituales. Obligada a renunciar como posee- 
dora única, la Iglesia Tradicionalista, a cargo del Padre Romo, incorporó la imagen de La Santa Muerte como un ángel más en su doctrina y modificó su aspecto al agregar carne a lo que antes eran simplemente huesos. Para los creyentes fue una herejía, y desató una nueva polémica. Es de nuestro interés analizar las formas y símbolos que los grupos marginales y excluidos construyen alrededor de este culto. Son ellos los que hacen hincapié en sus creencias y hacen alarde de los favores recibidos. Más aún, a través de ellos podemos comprender como reconstruyen el tiempo social en un presente que se alarga; y la manera en que traducen los riesgos de sus decisiones en peligros que derivan de algo que los rebasa.

Pero ¿Qué es el culto a La Santa Muerte? ¿Qué elementos de identidad cultural derivan de este culto? ¿Por qué es tan difundido en el submundo de lo marginal? Algunas pistas para responder estas interrogantes serán establecidas en este trabajo. Aunque es necesario señalar que son más las preguntas que respuestas encontradas en este texto.

\section{Tragedia y destino: la representación de la muerte}

El símbolo y la metáfora de la muerte han acompañado a todas las civilizaciones en el tiempo y el espacio. La vida y la muerte son inseparables. La vida exige desde sí a la muerte como su contrario, aquello que habilita el sentido de ser y estar en el mundo. En la eternidad la vida no tiene sentido, mucho menos la muerte. Se anularía como se anula la mentira en un mundo donde todo fuera verdad. Por tanto, el culto a la muerte es también un culto a la vida.

La historia de La Santa Muerte puede rastrearse de tiempo atrás y desde diversas vertientes: prehispánica, afroantillana, magia-brujería, etcétera.

En la época prehispánica tuvo una connotación particular. Era el símbolo que liberaba a los guerreros en la batalla y a las madres en el parto. Los sacrificios tenían un doble sentido: el hombre accedía al mundo del proceso creador y por la otra alimentaba la vida cósmica y social, que se nutría de la primera. (Ambrosio, 2003:34) Con el catolicismo se transformó la noción sobre este tema. La vida y muerte pasaron de ser un sentimiento colectivo como en los aztecas, a una noción individual. Los hombres ya estaban condenados de antemano (pecado original) pero podían salvarse si el arrepentimiento llegaba antes de la muerte. Después de esta nada habría que hacer. El culto a La Santa Muerte procede de un sincretismo entre ambas cosmogonías. Ambas reúnen la idea de que la muerte no es el fin del mundo, sino una nueva vida que no se desarrollará aquí. Junto a esta noción aparece la representación de que con la muerte se justifica la vida.

Pero el culto a La Santa Muerte no se hace explícito en el lenguaje hasta el siglo XX. Es cierto que trae de sí todo un sentido de la historia y cultura del mexicano, mas no es hasta este momento en que el culto aparece como un todo organizado, un sistema de creencias y rituales que establecen membresía entre los que la profesan. Según cuentan los santeros y curanderos del mercado Sonora, el culto apareció en el poblado de Tepatepec, cabecera del municipio de Francisco I. Madero, en el Estado de Hidalgo (ubicado a 49 kilómetros de Pachuca) hacia la década de los sesenta. En ese lugar murió una otomí de nombre Albina, famosa por sus curaciones milagrosas. Esta mujer tenía en su casa un esqueleto de madera, al que se considera la verdadera imagen de la Santa Muerte. Existen otras versiones que aseguran que surgió en 1800 en el Puerto de Veracruz; a un brujo se le apareció en su vivienda, luego alguien hizo una réplica de la imagen en versión femenina, de ahí que haya una figura macho y otra hembra.

Alrededor del culto se ha establecido una serie de creencias y rituales diversos, que a veces se confunden con la santería y el vudú. El sincretismo en la creencia nos lleva a rastrear las formas y símbolos vinculados con la Virgen del Carmen en la tradición mariana católica. De igual forma se encuentran elementos de la tradición afro-cubana con las imágenes de Oyá, la señora de los 
panteones y del vudú con la imagen de Oggún, imagen que protege de los accidentes violentos.

Para los creyentes La Santa Muerte tiene un doble rostro: es maldita y bondadosa con los que le profesan devoción. La imagen femenina es bondadosa y protege del mal a quién la invoca. En su mano derecha lleva una balanza y es de color blanco. La imagen del macho carga en su hombro la guadaña y es invocada por aquellos que desean un mal o la muerte a su enemigo. Pero el culto no es sólo en blanco y negro, también expresa matices de deseos, odios y sentimientos a través de una variedad de colores como el amarillo, violeta, rojo, etcétera.

Paradójicamente, aquellos que se encomiendan al culto no podrán salirse hasta que ella decida, es decir, hasta que le rindan cuentas entregando su vida. Según los devotos, se necesita de muchos cuidados y devoción por parte de quien ora. La disciplina de rezar a la misma hora los siete días de la semana:

En su altar le debes prender su veladora, cambiarle un vaso de agua limpia todos los días y ponerle tortillita quemadita porque eso es lo que come ella, se le tiene que poner para que te vaya bien en lo que hagas y ella te cuide (Testimonio de "LaDoña", Publicado en Diario Reforma el 7 de octubre del 2001).

La creencia dice que, aquellos que pierdan la fe, serán castigados en lo que más aman. Desgracias familiares, pérdida de la libertad y hasta ser asesinados son los castigos que, según sus adeptos, les impone a los que se atreven a abandonarla. Para Carmen, vendedora de artículos rituales en el mercado de Sonora, la mejor muestra de la forma en que se cobra La Santa Muerte es el caso del secuestrador "Mocha orejas" Daniel Arizmendi. Según dijo, el secuestrador perdió toda devoción a la imagen y esta se cobró con su familia: su esposa, hijo y hermano están en la cárcel al igual que él.

Pero aquellos policías y delincuentes que se encomiendan a ella tendrán su protección.
A muchos policías les gusta tener la protección superior de la muerte, pues ella les da premoniciones cuando puede estar en peligro su vida (Carmen, vendedora de figuras de la Santa Muerte, Mercado de Sonora).

Igualmente, relatan que se han presentado políticos que contienden por alguna candidatura.

Hay personas que andan en campaña, políticos que quieren ganar a como sea y por eso ofrendan a la Niña (Santa Muerte), y regresan después (Héctor, auxiliar en los locales de limpias del Mercado Sonora).

Pero no es sólo el bajo mundo el que implora el auxilio. Políticos y funcionarios de alto nivel, al igual que amas de casa le rezan. Cuenta la antropóloga Ortiz Echeniz, autora de un libro sobre tradiciones religiosas populares en México, que en cierta ocasión fue requerida como experta por un alto funcionario de la Presidencia de la República para que le explicara las funciones y alcances de una deidad tan poderosa como La Santa Muerte, deidad que pudo analizar cuando participó en algunos rituales en Las Choapas, Veracruz (González, 2001). ${ }^{2}$

Las amas de casa son otro núcleo social creyente en el culto, en parte derivado del clima de inseguridad que priva en el Valle de México. Muchas de ellas viven en zonas reconocidas como de alta delincuencia (Tepito, Iztapalapa, Gustavo A. Madero, etcétera) y su encomienda a la imagen es la de proteger a sus hijos y esposos cuando salen a la calle. Según relatan, la creencia en la muerte no excluye que sean guadalupanas o veneren a otros santos. Dicen que entre más se encomienden, mejor protegidas estarán por alguno de estos personajes que pueblan el jardín de lo religioso. Las amas de casa involucran a la familia en los rituales y prácticas del culto. Niñas y niños pueden ser observados en las visitas a los altares y en las procesiones que se llevan a cabo en la Colonia Morelos. 
Daniel Bell, sociólogo norteamericano, critica duramente este tipo de manifestaciones en forma de culto. Para él, la religión es la conciencia de la sociedad y forma parte de la capacidad integradora de los hombres frente a una modernidad que fragmenta los lazos sociales y vuelve etéreo todo compromiso y solidaridad. Según sus argumentos, la religión no deriva de ninguna cualidad utilitaria (auto interés o necesidad individual). El poder de la religión está en ser un imponente receptáculo del sentido de lo sagrado, aquello que es distinguido como la conciencia colectiva de un pueblo (Bell, 1994: 157).

Bajo esta lógica podemos decir que cualquier culto difiere de una religión formal en muchos aspectos. Primero, el culto pretende la posesión de cierto conocimiento esotérico que ha sido reprimido durante mucho tiempo. Segundo, el culto no vincula a los hombres en los ritos, por el contrario, hace sentir a los sujetos como si estuvieran explorando modos de conducta novedosos o hasta entonces reprimidos. Tercero, esta forma de lo religioso resalta la magia más que la teología, el vínculo personal con el gurú o con el grupo es mayor que con una institución o un credo. El culto tiene un apetito insaciable por el rito y el mito (Bell, 1994: 162).

Bell plantea una serie de equívocos en su argumentación. Es cierto que en el culto se da un sentido mayor a la magia y la adhesión al gurú, pero no necesariamente por un sentido utilitario, sino para que los participantes puedan resolver una necesidad inmediata, material o espiritual. No hay ese vínculo utilitario, al menos no en la relación inmediata con la imagen.

La relación utilitaria se da en ámbitos como los de la ciencia o la política a través de expectativas cognitivas. Es decir, se esperan ciertos resultados a partir de condiciones dadas. De no lograrse los fines, se desecha la expectativa y se construye otra. En cambio, en el culto se funda una expectativa de carácter normativo. Esto es, se invocan fines y metas a través de rituales y oraciones. Si las peticiones hechas a lo divino no se cumplen, la frustación por ello no implica el abandono de la expectativa. Por el contrario, se reafirma la convicción sobre el culto y se renuevan los votos para que otras peticiones sean favorecidas. En el caso de La Santa Muerte esto es evidente. Los creyentes se sienten protegidos por ella, y cuando les falla es porque así como da quita: "es la santísima y ante ella a todos les llega la hora", nos comenta uno de los policías con quien logramos platicar en el Centro de Energía.

Dos casos pueden ilustrar mejor lo que queremos explicar como expectativa normativa. El primero de ellos refiere a la captura en 1998 de Daniel Arizmendi, secuestrador que cortaba las orejas a sus víctimas para obligar a los familiares a pagar el rescate, quien es un devoto de este culto. En la casa donde lo capturaron, los policías encontraron un altar dedicado a La Santa Muerte. Antes de ser remitido a la cárcel pidió un favor a los policías y se lo concedieron: Arizmendi se aproximó al altar que tenía en un rincón de su guarida, tomó la escultura de La Santa Muerte, la envolvió con su chaqueta y pidió que se la guardaran (González, 2001).

—Ni modo, fue un mal día-, expresó a los medios de comunicación (Monsiváis, 1998).

El segundo caso fue el de Gilberto García Mena, alias "El June", capturado en el 2001. El principal operador del Cartel del Golfo era un devoto del culto. Cuando los policías entraron a su escondite vieron un altar con veladoras y leyendas que decían: "Dinero, ven dinero," o aquella otra, "Muerte querida de mi corazón, no me desampares con tu protección." Aún cuando el June fue capturado, se cuenta que aún en la cárcel mantiene el culto a la Muerte, con todo y que lo abandonó en los momentos cruciales (Corpus, 2006).

La representación de la muerte no refiere sólo a una exaltación de la magia, a un vínculo directo con el gurú, simplemente porque aquí el gurú es accesorio, prescindible. La representación de la muerte va más allá. La representación en general, tiene una doble acepción paradójica. Por un lado, la representación evoca la ausencia de algo. Por otro lado, hace visible esa ausencia en 
la presencia de algún objeto que condensa aquello que no es visible. La Santa Muerte es, en este caso, la representación de la ausencia de vida, del momento en que llegaremos a ella sin darnos cuenta. Para hacerla visible se han creado objetos que reflejan la fragilidad del ser humano, su propio esqueleto que lo persigue. El hombre representa sus miedos en la fragilidad de su cuerpo, en la finitud de su vida. La Muerte representa lo infinito del mundo contenido en lo simbólico de la vida.

Para los seres humanos que se mueven en la frontera de la legalidad, que arriesgan su vida cotidianamente, la representación de la muerte los acompaña. Ninguno como ellos muestran su miedo a los cuerpos (el propio y los ajenos) y simbólicamente caminan por la calle huyendo de sí mismos. La Santa Muerte es la representación de vencer su propia muerte biológica. La tradición considera a la imagen tan poderosa como la figura de Cristo, quien fue vencido en la cruz por la muerte. El culto expresa el concepto de un espíritu sagrado, el más potente después de Dios e igual a Cristo. ${ }^{3}$ Militares, policías, ladrones y narcotraficantes portan un dije o un escapulario ostensible con aquella imagen. Algunos otros llevan tatuajes en la espalda: "llevo a la Santa en la espalda para que me proteja, porque de frente yo me defiendo", fue la declaración de un interno del Reclusorio Norte.

La Santa Muerte representa la eterna lucha entre el bien y el mal. Pero el bien tiene una irreductible desventaja: no tiene futuro, mientras que el mal sí. El bien no tiene ventaja porque todo en él es un estado de perfección y equilibrio estático. La moral al presentarse como portadora del bien no deja espacio para la discusión, desde sus principios todo está dicho. En cambio, el mal tiene futuro, pues es tan impredecible que a cada momento cambia las condiciones de existencia de los hombres. El mal es el catalizador por el que se puede acceder al bien. (Luhmann, 1996: 24). Los diez mandamientos de la Ley parten de una negación de los valores buenos para alcanzar el paraíso: no matarás, no desearás a la mujer de tu prójimo, etcétera. El bien necesita del mal para existir y viceversa. Cada uno es la ausencia del otro. La Santa Muerte representa esta lucha desde la maldad. Sabe que sólo en la redención de la muerte, los "malditos" como se les califica en la sociedad, podrán alcanzar el paraíso que se les ha negado en este mundo.

Podrán algunos alcanzar el paraíso negado, pero mientras, en este mundo, buscan hacer la vida difícil -quizás un infierno- a los otros. Así lo ilustran las distintas oraciones que a continuación presentamos:

1. Muerte santísima, los favores que me tienes que conceder. Harás que venza todas las dificultades y que para mi no haya nada imposible, ni obstáculos infranqueables, ni tenga enemigos, ni que nadie quiera hacerme daño, que todos sean mis amigos y que yo salga vencedor en todas las empresas que haga (Consultado en http://www.santamuerte.galeon. com/cvitae715539.html, 12 de enero del 2008).

2. Muerte querida de mi corazón no me desampares de tu protección, y no dejes a Fulano un solo momento tranquilo, moléstalo a cada instante y no dejes de inquietarlo para que siempre piense en mí (Consultado en http://www.santeriareligionl0l. com/blog/?p=66; 23 de febrero del 2008).

3. Muerte querida: yo te pido con todas las fuerzas de mi corazón, que así como Dios te formó inmortal y poderosa dueña y reina de las tinieblas del más allá, que con ese gran poder que tienes sobre todos los mortales, hagas que Fulano... no pueda en mesa comer, ni en silla sentarse, ni tranquilidad tenga, deseo que lo obligues a que humilde y rendido venga a mis pies y que nunca se aleje de mí (Rezar tres Padre Nuestro) (Consultado en http://www. santamuerte.galeon.com/cvitae715539.html; 12 de enero del 2008).

Resulta un tanto paradójico lo extendido del culto a la muerte en el mundo de la ilegalidad. Si todos se encomiendan a La Santa Muerte es de esperarse un corto 
circuito de los favores que la imagen tenga que conceder cuando dos o más creyentes tengan que enfrentarse y ambos invoquen su presencia. Esto es simbólicamente imposible para estos creyentes, para ellos la muerte sabe de antemano quién habrá de perder en la batalla.

Esta tradición que en últimas fechas ha crecido en la Ciudad de México nos remite a la reinvención de la tragedia griega. Los héroes en la tragedia sabían su destino pero no podían esquivarlo. Aceptaban su destino como algo irremediable y esperaban el desenlace final de la trama de su vida. Los narcotraficantes, policías y delincuentes saben de antemano su destino: la muerte. Sobre ella corren un velo simbólico y dejan el destino en manos de la simbolización de la muerte. Saben que tarde o temprano tendrán que rendirle cuentas. Bien dice Homero en la Odisea "Dame un héroe y te escribiré una tragedia" (Gil Villegas, 1997: 19).

\section{Los umbrales de la catástrofe: del riesgo al peligro}

La tragedia y el destino aceptados en el culto a La Santa Muerte contrastan con la idea de la contingencia en la modernidad. Todo puede ser de otra manera, es una de las formas de entender el mundo moderno. No hay nada definitivo, es posible modificar el futuro a partir de las decisiones en el presente. No existe el destino como un camino al que irremediablemente uno llega. Uno no puede evitar la muerte, pero si puede evitar llegar antes a ella a través de cambiar hábitos de vida, situaciones de riesgo y no exponerse a accidentes.

La noción de temporalidad en la modernidad nos lanza constantemente al futuro. La frase no como un proyecto a seguir sino como un mosaico que se modifica constantemente, un calidoscopio que a cada actuar en el presente se modifica. El futuro es algo que está en las decisiones que cada uno asuma en el presente. Pero no quiere decir que podamos conocer el futuro, indica que la única certeza que tenemos sobre él es que será distinto al presente. En el culto a La Santa Muerte el tiempo se anula. No existe el futuro, sólo un presente permanente, una sucesión infinita de presentes en el que los creyentes tienen que estar conscientes porque en cualquier momento ese presente se podría anular. Borges ilustra esta idea del presente y la muerte en su ensayo Historia de la eternidad: el presente es de todos; morir es perder el presente, que es un lapso brevísimo. "Nadie pierde el pasado ni el porvenir, pues a nadie pueden quitarle lo que no tiene" (Borges, 1999: 111).

Ahora bien, lo contingente de la sociedad moderna se ha traducido en riesgos que pueden ser modificados. El concepto de riesgo implica amenazas futuras derivadas de decisiones en el presente. La oposición al riesgo no es la seguridad, no hay seguridad $100 \%$ garantizada, siempre hay riesgos en los esquemas de seguridad (Luhmann, 1992: 51). El riesgo de morir en un choque automovilístico llevó a los expertos a decidir sobre esquemas de seguridad que disminuyeran la mortalidad en los accidentes de tránsito. Para ello inventaron el sistema de bolsa de aire colocado en el tablero del auto. Cuando sucede un impacto este se activa amortiguando el golpe. La decisión de colocar este sistema redujo la mortandad por golpe en el parabrisas, pero abrió el riesgo de morir asfixiado por la bolsa de aire. Dicho ejemplo nos ilustra que no son los mecanismos de seguridad los que eliminan el riesgo. Por el contrario, son ellos los que abren otros riesgos.

La forma de eliminar un riesgo es asumir otros riesgos, es decir, asumir otras decisiones que puedan evitar una amenaza futura. Pero al asumir otras decisiones estamos abriendo un horizonte infinito de posibilidades y con ello un mundo igualmente infinito de amenazas. El futuro y sus consecuencias dependen de las decisiones de los sujetos en el presente (De Giorgi, 1997: 5).

En oposición a la idea de riesgo está la noción de peligro que dominó ampliamente al mundo previo a la modernidad. El peligro no es otra cosa que la amenaza futura que no puede ser evitada por el que la padece. Un volcán en erupción, un terremoto o un huracán, son todos fenómenos que escapan al control del hombre. Por tanto son peligros. Sin embargo, con el advenimiento 
de la modernidad los peligros fueron transformados en riesgos. El desarrollo de tecnología antisísmica transforma el peligro de padecer un terremoto en un riesgo que se asume al decidir construir con esa tecnología y no con otra. Igual ocurre con los huracanes y las erupciones de los volcanes. El peligro ha sido develado para dar paso al riesgo y con ello a la decisión y responsabilidad en los hombres.

La religión tiempo atrás actuó (y lo sigue haciendo) en el peligro. Lo que acontecía en el mundo era una decisión de lo divino sobre las personas. El destino de cada uno estaba trazado de antemano y los milagros eran advertencias de Dios sobre su poder para demostrar que, bajo su voluntad, el mundo podría ser de otra manera. La noción de pecado en el cristianismo refería a la transgresión de la voluntad de Dios, creyendo poder construir el mundo de otra manera.

Pero la noción de peligro en la religión está confrontada con la del riesgo en la modernidad. Esta situación es clara en el caso del culto a La Santa Muerte. Los participantes de la violencia pudieran decidir no seguir más, pero encubren su decisión bajo la forma de un destino que no pueden evitar. Por eso ven en la figura de la muerte el umbral de la catástrofe, umbral que es el límite entre el riesgo y el peligro. Para muchos policías encomendarse a La Santa Muerte es una decisión asumida en el presente para ocultar las amenazas que les depara el futuro, amenazas que no asumen como decisión propia, sino como tragedia de su actividad. Los santeros del Mercado de Sonora defendían a la imagen cuando se les preguntaba por qué si es tan poderosa dejó que ocurriera la captura del secuestrador Arizmendi, respondiendo que nada sirve cuando el destino está marcado.

El relato de la muerte anunciada de un policía puede ilustrarlo: En febrero de 1999 fue acribillado frente a las oficinas de la Procuraduría General de la República, en la Ciudad de México, el comandante José Francisco Sánchez Naves (González, 2001). Todo apuntaba a un claro ajuste de cuentas del narcotráfico. José Sánchez no era cualquier policía, había pertenecido al grupo de élite de la Policía Judicial Federal y sus hazañas se podían contar por decenas. Entre estas hazañas destaca el decomiso más grande en la historia de la guerra contra el narcotráfico: ocho toneladas de cocaína incautada en Oaxaca proveniente de Colombia, concretamente de Medellín donde aún mandaba Pablo Escobar Gaviria.

Sánchez Naves había sido subdelegado de la PJF en los estados de Sinaloa, Oaxaca, Nuevo León, Distrito Federal, Sonora y Chihuahua. En 1995 sufrió su primer aviso: fue víctima de un atentado en Acapulco, del que salió ileso. Tuvo algunos otros avisos, pero nunca hizo caso. Sus compañeros recordaban que era un fiel adepto a la Santa Muerte y al momento de su deceso traía consigo un escapulario de la imagen.

Los creyentes del culto señalan con insistencia que no pueden decidir sobre su propio futuro. Sólo pueden encomendarse a la muerte como último destino. No hay decisión, no hay futuro para ellos. Aunque esto a últimas cuentas es una ilusión. El decidir es una decisión que abre un sin fin de riesgos que ni la tradición puede prever.

El mundo, aparte de ser contingente, se vuelve ininteligible. La muerte no protege de nada. Los adeptos no saben cuándo los protegerá. Los peligros no son otra cosa que riesgos encubiertos bajo el manto de la magia. Resulta poco lógica la argumentación recurrente: la muerte te protege todas las veces, excepto la última. Resulta incierto conocer el futuro, pero desde la óptica de la religión nadie puede conocer el destino que le depara, sólo Dios. Querer hacerlo es querer igualarse a Dios y, como los textos sagrados lo señalan, Lucifer quiso hacerlo y cayó en la desgracia.

La narrativa de La Santa Muerte se vuelve circular: te protege todas las veces, excepto la última. Así como te da, quita. Estas dos expresiones nos permiten observar la complejidad de la creencia y su tendencia a mitigar la incertidumbre del mundo en la imagen. Es depositar la responsabilidad de las decisiones en instancias externas que puedan dar certeza, aunque ello sea sólo una ilusión. 
Santa entre los Malditos. Culto a La Santa Muerte

\section{La inclusión en la exclusión: La Hermandad en la muerte}

Italo Calvino escribió acerca de la ciudad y los muertos en su libro Las ciudades invisibles: "Llega un momento en que de la gente que uno ha conocido son más los muertos que los vivos (...) Tal vez sea una señal que yo también estoy muerto y además es señal que el más allá no es feliz" (Calvino, 1998: 108).

Con esta idea se señala que la tradición de la que hemos estado hablando no tiene solamente implicaciones simbólicas y culturales. Sus repercusiones alcanzan ámbitos como la política y el derecho. Los creyentes son personajes que se mueven en la frontera de la legalidad. Su trasgresión a la ley los excluye del sistema del derecho y su poder no legitimo los vuelve parias de la política. Los policías están constantemente cruzando esta frontera, y aplican métodos ilegales para aplicar la ley. Es el caso de la tortura a los delincuentes. La fragilidad de esta frontera hace que policías cambien de bando y que los delincuentes sean aclamados como héroes tal y como pasa con los narcotraficantes.

La intención del sistema del derecho de ampliar y controlar los actos de corrupción y delincuencia ha llevado a un incremento de las disposiciones legales que buscan hacer más inclusiva las actuaciones de los ciudadanos. Se incrementan los controles en las oficinas públicas para evitar la corrupción, se tipifican nuevos delitos para castigar a los delincuentes (es el caso de la petición de reducir la edad legal de los delincuentes para hacerlos sujetos de procesos penales). Pero la pretensión de ser más inclusivos no conduce a disminuir la exclusión. Por el contrario, provoca un aumento de la exclusión. A mayores controles se incrementa la demanda por agilizar los trámites. Al tipificar un mayor número de delitos en el código penal se incrementa el universo de delincuentes, reales y potenciales.

La sociedad en su conjunto prefiere ignorar el submundo de la delincuencia, como si no existiera. Pero el hecho de ser excluida no la vuelve ausente del mundo social. Por el contrario, establece redes de inclusión en la exclusión. Forma pandillas, carteles del narcotráfico, mafias, poderes paralelos y parasitarios con sus propios esquemas jurídicos, sus reglas de membresía. Establece una normalidad subterránea respecto a la normalidad de la política y el derecho. En este sentido, tiene más poder un delincuente que un político o un policía. Las redes de la inclusión en la exclusión proveen al delincuente actuar ilegalmente en la legalidad. Organizaciones como la mafia italiana o los carteles de la droga actúan de manera jerarquizada, con reglas y normas que permiten ser inclusivos. Su rompimiento da paso a la guerra y a los asesinatos que escandalizan. El jardín de la muerte del narcotráfico en México está sembrado por tres mil ejecuciones sólo en el 2007 (Gandaria, 2007).

La exclusión crea necesidades: sin dinero no se paga la renta, sin renta no se tiene casa, no se tiene que comer. Para los excluidos no hay filtros simbólicos que medien socialmente sus necesidades, al menos para mantener latentes las expectativas de bienestar (Corsi, 1999: 31). Esta es la mejor manera en que se amplían las redes inclusivas de las organizaciones de delincuentes. Así funciona con los carteles de la droga en Colombia y México. La mafia italiana se finca en esta expectativa.

En México, una buena parte de la delincuencia común se organiza en bandas, pero existe otro sector que es diáfano, disperso, sin ningún punto de articulación. Actúan de manera aleatoria y arbitraria. Y es aquí donde se revela la importancia del culto a La Santa Muerte, culto que permite articular una red de inclusión entre delincuentes, policías y políticos, sin la pretensión ni la forma de la Camorra italiana o la de los carteles de la droga latinoamericanos. El Estado puede combatir los vínculos entre delincuentes y policías desde el derecho, la economía y la fuerza legítima. Sin embargo, la gran pregunta que queda en puntos suspensivos es la siguiente: icómo combatir dichos vínculos afianzados en una creencia compartida?.

A diferencia de los otros sistemas sociales, la religión es totalmente inclusiva. Los sistemas de creencia 
reconocen a los seres humanos como hijos de una divinidad. En el caso del cristianismo todos somos hijos de Dios y, aún con el pecado original, podemos aspirar al paraíso. Los excluidos de otros sistemas son incluidos en el sistema de la religión. De ahí la fuerza de lo religioso en muchos ámbitos, entre ellos los "malditos", los criminales.

Dentro de la vertiente religiosa, La Santa Muerte se muestra más inclusiva que cualquier otra dimensión religiosa. Para muchos de los reos en el Reclusorio Norte la muerte es más justa que Dios, pues este último no es parejo. En cambio, la muerte es pareja y justa, no importa quién seas ni cuánto tengas, ni cuánto poder ejerzas. Ella, la muerte, es igualitaria y democrática.

En 1998, Víctor Soto Camacho, Vicepresidente de la Comisión de Seguridad Pública de la Asamblea Legislativa del Distrito Federal, informó sobre una pesquisa a su cargo. Revelaba las vinculaciones, estructura, lenguaje, usos y costumbres del crimen organizado en la Ciudad de México. Las conclusiones no fueron muy sorprendentes. Según este documento, los mandos medios policíacos protegen a las bandas. Además, participan en rituales en los que se da paso a la iniciación a una hermandad de sangre entre policías y delincuentes. Esto nos dice de una vasta red inclusiva en la exclusión (González, 2001).

Dicha organización no es pública. Se mantiene en el más absoluto silencio. Entre sus miembros existe un código de silencio. No pueden hablar de cómo funciona. A pesar de ello podemos estar seguros de algo: no es un ente organizacional complejo como la mafia, ni siquiera una instancia de reparto como los carteles. Funciona simplemente como un código de honor entre sus miembros, los cuales en no pocas ocasiones se enfrentarán en la calle, y al menos alguno tendrá que perder. Una regla para no hacer evidente el altar de veneración es colocar en el lugar de la imagen, un clavel blanco y varias velas a su alrededor. Ello permite cierta discreción en cuarteles de policía y barrios como Tepito.
Una discusión por demás interesante podría establecerse entre la teoría del delincuente de Horkheimer y la inclusión en el culto. Para Horkheimer, la sociedad burguesa impone su visión sobre el delincuente, ese ser débil, embrutecido que debe ser castigado en las cárceles para que paguen su culpa. Cuando estos delincuentes son detenidos deben padecer y sufrir de manera ciega la pena. La cárcel no es el lugar para rehabilitar. La cárcel es como una enfermedad incurable. Lo revelan incluso los rostros de los presos, su marcha prudente, su forma minuciosa de pensar. Como los enfermos, no saben hablar más que de la propia enfermedad (Horkheimer, 2000: 271). ${ }^{4}$

Pero la exclusión que la sociedad burguesa aplica al delincuente no es total como afirma Horkheimer. Quedan fisuras sobre las que se finca la resistencia, la forma de ser inclusiva. La muerte es el mejor vehículo para reafirmar la vida en las cárceles. Según reportajes amplios, en la cárcel va en aumento el culto a La Santa Muerte.

Los reclusos buscan en la tradición la energía y la sanación para soportar los años de encierro. Hechas de diversos materiales, talladas a mano o plasmadas en una pintura, y hasta tatuadas en alguna parte del cuerpo, la mayoría de los reos rinde tributo a la muerte

(...) sobre todo aquí, en donde hay muchos pecados. Le digo 'cuídame', porque en cualquier momento puedo encontrar la muerte. Ya he visto varios compañeros que han muerto. Ella es mi protectora... le pedimos que nos cuide (Castellanos, 2004).

El rendir culto genera una especie de código entre los internos. Una identificación que les permite resistir el control sobre el cuerpo y la mente impuesta por la institución carcelaria. De hecho, se da una forma de solidaridad entre los reos, aunque no excluye las riñas y el cobro de viejas cuentas. Por sobre todo esto, el culto se revela como una forma de resistencia a la "normalidad" impuesta sobre ellos. 


\section{Conclusiones}

El culto a la muerte es una de las tradiciones simbólicas más complejas y características de México, del siglo XXI. La forma en que se muestra el culto y devoción a la muerte se extiende por diversos lugares. Desde las zonas rurales hasta las grandes ciudades. Pero esta tradición ha encontrado un espacio organizado donde se vuelve visible, cuyo contenido rige la vida de ciertos sectores que se mueven en la frontera de la clandestinidad.

El culto a La Santa Muerte, más allá de sus contenidos esotéricos, es un símbolo que demuestra la percepción sobre la fragilidad de la vida y la necesidad de reivindicarla a través de creencias y rituales que la mantengan presente. En la muerte se han encontrado diversos sentidos. El primero de ellos remite a la idea de entender la vida como una tragedia y un destino que no podemos evadir. Los grupos de alto riesgo: policías, militares, prostitutas, entre otros, han hecho suya esa tragedia, la cual asumen como un destino inevitable. En segundo lugar queda la percepción de incertidumbre en un mundo que cambia rápidamente y en el que la supervivencia es moneda corriente. Los riesgos son asimilados como peligros y es La Santa Muerte la catalizadora de los miedos y angustias. Aunque al final ella no resuelva la duda, queda la expectativa de llegar algún día con ella. Un tercer y último punto nos remite a un modo de inclusión que los "malditos" han encontrado en el culto. A través de ella manifiestan un sentido de justicia y hermandad que no les proporciona en lo inmediato otro medio. Son hermanos y justos, aunque sea en la desgracia.

Concluimos con dos citas que muestran la fragilidad humana de la que hemos hablado:

Jesús con la mano derecha alzada ordenó a Lázaro levantarse de su tumba. El mayor milagro de Jesús - arrebatar a la muerte su monopolio sobre los hombres-fue interrumpido abruptamente por María Magdalena, quien entre sollozos reclamaba al Mesías la injusticia que se hacía con Lázaro, pues nadie es tan malo como para morir dos veces (Saramago, 1999: 494).

Se cree morir por la Clase, se muere por la gente del Partido.

Se cree morir por la Patria, se muere por los Industriales

Se cree morir por orden de un Estado, se muere por el dinero que lo sostiene

Se cree...

¿Por qué creer en una oscuridad tal?

¿Creer? ¿Morir? ... ¿Cuándo se trata de aprender a vivir? (Marcuse, 1999: 235).

\section{Notas}

${ }^{1}$ La Iglesia Tradicionalista retiró de su iconografía la imagen de la Santa Muerte con el fin de facilitar su reingreso en el padrón de asociaciones religiosas de la Secretaría de Gobernación aunque sin éxito. Martínez, Fabiola (2007) Busca iglesia de La Santa Muerte registro ante SG, La Jornada, México, 21 de Julio.

${ }^{2}$ Esta vinculación de la magia con la alta política no es rara en Latinoamérica. Varios presidentes admitieron gobernar en parte a la visión de su médium, chamán o adivino como fue el caso de Carlos Andrés Pérez en Venezuela, Fernando de Mello en Brasil y Carlos Menem en Argentina.

${ }^{3}$ La Santa Muerte los acoge a todos, ya que es la que "venció a Cristo", como salmodian los creyentes. La madre de todas las vírgenes, de los santos, la que une a los vivos y a los muertos en su último rostro. Entrevistas a devotos de la Santa Muerte durante la peregrinación al altar en la Colonia Morelos, domingo 26 de junio del 2007.

${ }^{4}$ Horkheimer, Max y Adorno, Theodor, Dialéctica de la Ilustración, Madrid, 2000.

\section{Bibliografía}

Ambrosio, Juan, 2003, La Santa Muerte. Biografía y culto, Editorial Planeta, México.

Arendt, Hannah, 1999, Los orígenes del totalitarismo, Alianza Editorial, Madrid. 
Aridjis, Homero, 2003, La santa muerte sexteto del amor, las mujeres, los perros y la muerte, Alfaguara, México.

Ariés, Philippe, 2000, Historia de la muerte en occidente, Acantilado, Barcelona.

Bell, Daniel, 1994, Las contradicciones culturales del capitalismo, Alianza Editorial, Madrid.

Borges, Jorge Luis, 1999, Historia de la eternidad, Alianza Editorial, México.

Calvino, Italo, 1998, Las ciudades invisibles, Ediciones Siruela, Madrid.

Castañeda, Fernando, 2000, Redes de inclusión: la construcción social de la autoridad, UNAM-Miguel Ángel Porrúa, México.

Castellanos, Laura, 2004, Lasantadelosdesesperados, Suplemento Masiosare, Diario La Jornada, núm. 333, 9 de mayo.

Corpus, Aline, 2006, Invade Santa Muerte a Tijuana, Diario el Norte, 18 de septiembre.

Corsi, Giancarlo, 2000, "Las redes de la exclusión”, en Castañeda, Fernando, 2000, Redes de inclusión: la construcción social de la autoridad, México, UNAM-Porrúa.

De Giorgi, Raffaele, 1997, "Del Riesgo de la inseguridad al riesgo de la pérdida de control", en Revista Política y Sindicatos, núm. 34, Norlatina Consultores, Noviembre, México.

Eco, Humberto, 1986, Los límites de la interpretación, Lumen, Madrid.

Gandaria, Manrique, 2007, Advierten sobre militarización en 2008, El Sol de México, México, 21 de diciembre.

Gil Villegas, Francisco, 1997, Los profetas y el Mesías, Lukács y Ortega como precursores de Heidegger, El Colegio de México-Fondo de Cultura Económica, México.

González Rodríguez, Sergio, 2001, Bajo la protección de la Santísima, Diario Reforma, 7 de octubre.
Heidegger, Martin, 2001, El concepto del tiempo, Editorial Trotta, Madrid.

Horkheimer, Max y Adorno, Theodor, 2000, Dialéctica de la Ilustración, Editorial Trotta, Madrid.

Ibáñez, Jesús, 1990, Nuevos avances en la investigación social: la Investigación social de segundo orden, Suplemento 22, Anthropos, Barcelona.

Luengo González, Enrique, (comp.), 1991, Secularización, modernidad y cambio religioso, México, Universidad Iberoamericana, México.

Luhmann, Niklas, 1992, Sociología del riesgo, Universidad de Guadalajara, México.

Luhmann, Niklas, 1996, "Políticos, honestidad y la alta moralidad de la política”, en Revista Nexos, núm. 219, Mayo, México.

Marcuse, Herbert, 1999, El hombre unidimensional, Ariel, Barcelona.

Monsiváis, Carlos, 1998, Fue un mal día para Daniel Arizmendi, Semanario Proceso núm. 1138, 23 de agosto.

Paz, Octavio, 1990, El laberinto de la soledad, Fondo de Cultura Económica, México.

Red de la Santa Muerte en Internet, http:/www.santamuerte.galeon.com/index.html.

Ricoeur, Paul, 2000, Teoría de la interpretación, Siglo XXI, México.

Saramago, José, 1999, El Evangelio según Jesucristo, Alfaguara, México.

Simmel, George, 2000, El individuo y la libertad, Península, Barcelona.

Wilson, Bryan, (comp.), 1998, Secularización e integración social, Leuven University Press, Bélgica.

Zermeño Padilla, Guillermo, 2002, La cultura moderna de la historia, El Colegio de México, México. 